\section{Doing Business with the Office of Energy Efficiency and Renewable Energy}

The U.S. Department of Energy's (DOE) Office of Energy Efficiency and Renewable Energy (EERE) works with businesses, industries, universities, and other stakeholders to drive innovation and deploy clean energy.

This fact sheet includes financial assistance and business opportunities that EERE offers.

\section{Financial Assistance}

EERE encourages clean energy research, development, demonstration, and deployment (RDD\&D) primarily through financial assistance awards to the private sector. These awards transfer money, property, or services to recipients to accomplish public purposes authorized by federal statute. For example, a financial assistance award might fund research to improve solar cell efficiency.

Funding awards may be competitive or noncompetitive and include both direct and indirect assistance. EERE directly funds grants, cooperative agreements, continuation awards, and renewal awards in addition to providing indirect financial assistance through subawards, laboratory subcontracts, and cooperative R\&D agreements.

\section{Competitive}

Most EERE grants and cooperative agreements foster competition among businesses, industries, universities, and other stakeholders. EERE solicits grant applications in specific program areas and selects projects based on a merit review process that includes industry and technology experts.

Cooperative agreements are similar to grants, but they require more involvement from the federal government. The federal government exercises more control in technical implementation of work performed through agreements. This may include project collaboration, project management participation, or intervention in the activity.

The Tribal Energy Program website, www.eere.energy.gov/ wip/tribal.htm/, details financial opportunities for Native American tribes, including grants and project financing. DOE provides financial and technical assistance to tribes for clean energy projects.
Financial Assistance Process Congressional appropriation

Department of Energy \& EERE allocation

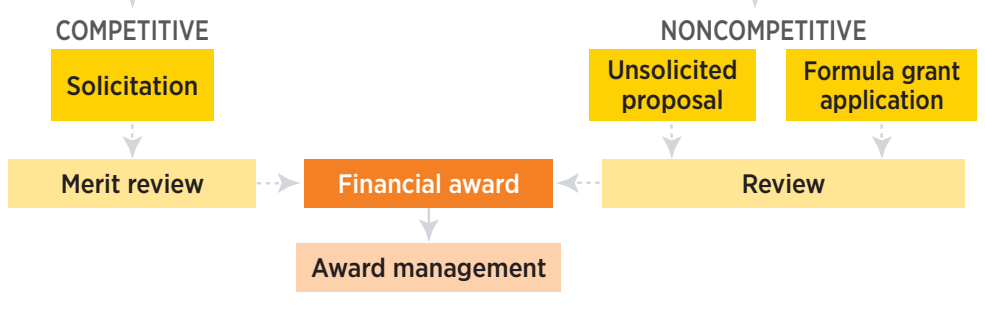

DOE's world-class national laboratories support many EERE activities, and often offer EERE-funded financial opportunities for industry and outside organizations.

Laboratory subcontracts, the most common opportunity, are normally competitively selected and begin with a solicitation. Contracting staff at the national laboratories evaluate proposals and subcontracts. Visit the individual laboratory websites to learn more.

In some cases, more than one business or organization may participate in a project funded by a grant or subcontract. In these cases, a subaward may be applicable. Subawards financially support businesses or organizations that work on a project but are not the primary awardee. Grant proposals often plan for subawards, allowing organizations to bring in outside expertise that will benefit the project. Subawardees are subject to the same guidelines and requirements as the primary awardee.

Entrepreneurs often pursue funding for clean energy innovations through an unsolicited proposal route with the Small Business Innovation Research (SBIR) or Small Business Technology Transfer (STTR) programs. DOE's Advanced Research Projects Agency-Energy (ARPA-E) also accepts proposals for transformational clean energy innovations through high-risk, high-reward R\&D.

Federal agencies with substantial R\&D budgets operate the SBIR/STTR programs, setting aside funding for tailored

\section{Special Programs}

- Small Business Innovation Research Program (SBIR), www.eere. energy.gov/office_eere/sbir.html

- Small Business Technology Transfer Program (STTR), wWw.eere. energy.gov/office_eere/pdfs/sbir_program_information_sheet.pdf

- Advanced Research Projects Agency-Energy (ARPA-E), arpa-e.energy.gov 
competitions among small businesses only. In 2007, the America Competes Act established ARPA-E to fund innovative projects that will develop "game-changing" technologies to reduce America's dependence on foreign energy imports; reduce U.S. energy-related emissions (including greenhouse gases); improve energy efficiency across all sectors of the U.S. economy; and ensure that the United States maintains global advanced technology leadership.

\section{Noncompetitive}

EERE provides formula grants to state and local governments for clean energy projects. DOE's Weatherization Assistance Program, State Energy Program, and the Energy Efficiency and Conservation Block Grant Program all fund state and local clean energy efforts. Funding formulas for these programs are set by federal statute. State energy offices may have their own programs and financial opportunities associated with these federal formula grants.

Financial assistance may also be awarded on a noncompetitive basis through unsolicited proposals. Applications for assistance that are not submitted at the request of the government or in response to a solicitation announcement are considered "unsolicited proposals." Contact DOE's central point for unsolicited proposals, the National Energy Technology Laboratory, for more information.

Through cooperative research and development agreements (CRADAs), DOE funds national laboratory collaboration with the private sector to further R\&D. Unlike other financial opportunities, CRADAs do not result in a financial award. In simple CRADA partnerships, each party contributes equally to a project in terms of labor, funding, and facilities. In more complex arrangements, the private partner may opt for a "funds in" arrangement, in which it defers part of the laboratory's expenses.

\section{Business Opportunities}

Another way EERE partners with business is through procurement contracts. The federal government buys, leases, or barters property or services through these contracts. For example, EERE would use a procurement contract to purchase computers for its employees. The General Service Administration (GSA) maintains a schedule and bidders list from which federal agencies can obtain goods and services. The first step toward selling products and services to the federal government is being added to the GSA schedule and bidders list.
Private sector organizations may also partner with an ESCO, or energy service company, to provide services to federal facilities. An ESCO is a commercial business that designs and implements energy savings projects, energy conservation, energy infrastructure outsourcing, power generation and energy supply, and risk management. DOE maintains a list of qualified ESCOs contracted to provide energy savings performance contract services.

EERE's Federal Energy Management Program offers a comprehensive guide "Selling Energy-Efficient Products to the Federal Government" at www.eere.energy.gov/femp/pdfs/ selling_eeproducts_to_gov.pdf. The guide gives tips on the "ABCs of Government Purchasing," how to get on a bidder's list, special opportunities for small businesses, and more. The booklet includes links to additional online resources.

\section{Other Resources}

DOE's e-Center, e-center.doe.gov, contains more information on doing business with DOE. The website provides current business opportunities; registration for submitting proposals, bids, and applications; and information and guidance on the acquisition and financial assistance award process.

Register with FedConnect, www.fedconnect.net, to gain immediate access to information on current DOE business opportunities. This includes automated notifications and electronic access to download solicitations, submit bids or proposals and, if selected, receive awards.

FedBizOpps, www.fedbizopps.gov, is the system for all acquisition opportunities throughout the federal government. Register with both FedBizOpps and Grants.gov to receive e-mail notifications of new opportunities.

A video, "Doing Business with the Department of Energy DVD," is available that discusses the processes of doing business with DOE. Click the link under "Training" at $w w w$. management.energy.gov/business_DOE.htm.

\section{Learn More}

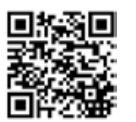

www.eere.energy.gov/business
EERE Information Center

1-877-EERE-INFO (1-877-337-3463)

www.eere.energy.gov/informationcenter

DOE/GO-102011-3305 • August 2011

Printed with a renewable-source ink on naber containina at least $50 \%$ wastenaner. includina $10 \%$ nost consumer waste. 